\title{
Uji Aktivitas Antioksidan dan Anti-aging Body Butter dengan Bahan Aktif Ekstrak Daun Kelor
}

\section{(Antioxidant and Anti-aging activity of Moringa Leaves Extract Body Butter)}

\author{
NUNUK ARIES NURULITA ${ }^{1,2, *}$, ELZA SUNDHANI ${ }^{1,2}$, IRMA AMALIA $^{1}$, FIFI RAHMAWATI $^{1,2}$ \\ NINA NURHAYATI DIAN UTAMI ${ }^{1}$
}

\author{
${ }^{1}$ Farmasi Fakultas Farmasi, Universitas Muhammadiyah Purwokerto, Jawa tengah, Indonesia \\ ${ }^{2}$ Cancer and Stem Cell Research Center, Universitas Muhammadiyah Purwokerto, \\ Jawa Tengah, Indonesia
}

Diterima 20 Juli 2018, Disetujui 10 September 2018

\begin{abstract}
Abstrak: Daun Kelor (Moringa oleifera) merupakan salah satu tanaman yang mengandung senyawa fenol seperti alkaloid, tannin, saponin dan flavonoid yang berkhasiat sebagai antioksidan dan antiaging. Penelitian ini bertujuan untuk membuktikan aktivitas antioksidan dan anti-aging daun Kelor serta membuat formulasi body butter dari ekstrak daun kelor. Proses ekstraksi daun Kelor metode maserasi dengan pelarut etanol 70\% perbandingan 1:10 kemudian dilakukan uji aktivitas antioksidan dengan metode beta caroten bleaching (BCB) dan anti-aging selanjutnya dilakukan formulasi body butter dengan bahan aktif ekstrak daun Kelor 0,5\%. Hasil penetapan kadar fenolik total dan flavonoid total ekstrak daun Kelor menunjukkan kadar yang dihasilkan yaitu sebesar 10,45 mgGAE/g ekstrak untuk fenolik total dan 5,53\% untuk flavonoid total. Hasil penelitian menunjukkan bahwa ekstrak daun kelor memiliki aktivitas penghambatan proses pemucatan beta karoten (inhibitor BCB) dan inhibitor enzim kolagenase dengan persentase penghambatan sebesar 47\%. Body butter ekstrak daun Kelor mempunyai potensi sebagai anti-aging melalui mekanisme antioksidan dan inhibitor kolagenase. Body butter ekstrak daun Kelor mempunyai penampakan organoleptis yang sudah baik dan menarik. Namun sifat fisik dari moringa body butter masih memerlukan optimasi agar lebih baik dan memenuhi standar yang telah ditetapkan.
\end{abstract}

Kata kunci: Moringa oleifera, anti-aging, BCB, inhibitor collagenase, body butter.

\begin{abstract}
Moringa leaf (Moringa oleifera) was one of plants that containt phenol compounds such as alkaloid, tannin, saponin and flavonoid that were useful as a antioxidant and anti-aging. The aim of this research was to prove antioxidant and anti aging's activity of Moringa leaf. The extraction process of Moringa leaf using maseration method with ethanol solvent $70 \%$ ratio $1: 10$, then the antioxidant properties determinate using beta carotene bleaching (BCB) and anti-aging's activity test was done, after that formulated the body butter with active ingredient of Moringa leaf extract $0.5 \%$. Moringa extract contains total phenolic $10.45 \mathrm{mg} \mathrm{GAE} / \mathrm{g}$ extract and $5.53 \%$ of total flavonoid. The result showed that Moringa leaf extract had inhibition of beta carotene bleaching properties as shown by BCB results. Moringa leaf extract inhibit the collagenase activity until $47.25 \%$ at concentration of $1600 \mathrm{ppm}$. Moringa leaf extract body butter has high potency of anti-aging through antioxidant and collagenase inhibitor mechanism. Moringa body butter had good organoleptic properties. However the physical properties of moringa body butter should be optimozed its composition to get the better one.
\end{abstract}

Keywords: Moringa oleifera, anti-aging, BCB, inhibitor collagenase, body butter.

*Penulis korespondensi: Hp. 082133709479

email: nunukariesnurulita@ump.ac.id, nunuknurulita@yahoo.com 


\section{PENDAHULUAN}

ANTIOKSIDAN sangat bermanfaat dalam pencegah penuaan dan penyakit degeneratif. Penuaan adalah proses yang akan terjadi pada semua makhluk hidup yang dapat menyebabkan perubahan progesif pada seluruh organ termasuk kulit. Pada sebagian orang proses menua terjadi sesuai dengan usianya namun adapula yang terjadi lebih cepat atau biasa disebut penuaan dini, hal ini dapat disebabkan karena akumulasi radikal bebas seperti paparan sinar matahari rokok dan polusi udara.

Dari data WHO menyebutkan bahwa rokok dapat membunuh 7 juta orang tiap tahunnya, dimana 6 juta juta merupakan perokok aktif dan sisanya termasuk perokok pasif(1). Konstribusi radikal bebas terhadap penuaan terjadi sejak awal dan semakin meningkat dengan bertambahnya usia. Jika jumlah radikal bebas melampaui efek protektif antioksidan akan menyebabkan proses penuaan serta penyakit degeneratif. Menurut WHO penyebab kematian terbesar saat ini adalah karena adanya penyakit degeneratif.

Tubuh menghasilkan senyawa antioksidan, namun antioksidan yang secara alami dihasilkan oleh tubuh jumlahnya terbatas untuk berkompetisi dengan radikal bebas yang dihasilkan setiap harinya. Oleh karena itu, dibutuhkan asupan antioksidan dari luar tubuh. Ada banyak bahan pangan yang dapat menjadi sumber antioksidan alami. Kebanyakan sumber antioksidan alami ialah tumbuhan dan umumnya merupakan senyawa fenolik yang tersebar di seluruh bagian tumbuhan(2).

Salah satu tumbuhan obat yang berpotensi sebagai antioksidan adalah Kelor (Moringaoleifera). Daun Kelor mengandung $\beta$-sitosterol $90 \mathrm{mg} / \mathrm{g}$, total fenolik $8 \mu \mathrm{g} / \mathrm{mL}$ dan flavonoid $27 \mu \mathrm{g} / \mathrm{mL}$, yang mana materi tersebut diduga berhubungan dengan aktivitas antioksidan(3.)

Penelitian sebelumnya tentang ekstraksi daun Kelor menunjukkan adanya aktivitas antioksidan dalam proses in vivo dan in vitro(4). Kandungan antioksidan pada daun kelor juga telah dibuktikan dengan menggunakan uji FRAP dengan hasil $65,53 \mu \mathrm{M} \mathrm{Fe} 2 / \mu \mathrm{g}(5)$. Dari data tersebut menguatkan penelitian ini untuk membuat sediaan kosmetik yang berbahan aktif ekstrak kelor.

Sediaan kosmetika untuk anti-aging yang paling banyak terdapat di pasaran adalah dalam bentuk lotion dan krim. Kedua sediaan tersebut mempunyai kelemahan dalam mempertahankan status hidrasi kulit, kemampuan melembutkan dan melindungi kulit dari pengaruh luar. Body butter adalah sediaan yang mempunyai kelebihan-kelebihan tersebut.
Kemampuan body butter dalam menghidrasi kulit, melembabkan dan melindungi dari pengaruh luar ikut memberi kontribusi sediaan sebagai anti-aging .

Penelitian ini dilakukan untuk memperkuat data ilmiah daun kelor sebagai anti-aging yaitu dengan uji aktivitas penghambatan $\beta$-caroten bleaching dan inhibitor kolagenase. Selain itu juga dilakukan pengujian kualitas body butter dengan bahan aktif ekstrak Kelor.

\section{BAHAN DAN METODE}

BAHAN. Bahan-bahan yang digunakan meliputi tanaman Kelor (Moringa oleifera), aseton, beta carotene, asam linoleat, etanol 70\%, kloroform, metanol, butanol, Asam asetat glasial, etil asetat, akuadest, lempeng KLT, $\mathrm{HCl} 25 \%$, kapas, pereaksi Liberman-Buchcard, pereaksi dragendroff, pereaksi $\mathrm{FeCl}_{3} 1 \%$, pereaksi $\mathrm{AlCl}_{3}$, Collagenase Assay Kit, Asam stearat, setil alkohol, gliserin, oleum cocos, oleum olivarum, TEA, BHT, nipagin, nipasol, oleum cacao.

Alat. Alat-alat yang digunakan dalam penelitian ini adalah rotary evaporator (IKA ${ }^{\circledR} 10$ Bassic), timbangan analitik, seperangkat alat maserasi, microplate 96 well plate (IWAKI), inkubator, alat uji daya lekat dan daya sebar, alat-alat gelas laboratorium (erlenmeyer, gelas beker, tabung reaksi, gelas ukur, pipet volume, pipet ukur, batang pengaduk, gelas arloji dan bunsen), pro pipet, rak tabung, stamper dan mortir, kertas saring, vial dan penutup, mikropipet, termometer, pinset, $\mathrm{pH}$ meter, viskometer dan spektrofotometer UV-Vis.

METODE. Preparasi Sampel. Sampel yang digunakan yaitu daun kelor diperoleh dari desa Toyareja, kec. Purbalingga, kab. Purbalingga. Daun kelor yang sudah terkumpul dilakukan sortasi basah untuk mengurangi bahan asing yang masih terbawa, kemudian dicuci dengan air mengalir dan dilakukan pengeringan sampai diperoleh sampel kering, kemudian dibubukkan menggunakan blender dan diayak sehingga dihasilkan serbuk yang siap digunakan untuk pembuatan ekstrak.

Ekstraksi. Ekstrak dari daun Kelor dibuat dengan maserasi, sebanyak 200 gram serbuk simplisia yang telah kering dimasukkan dalam wadah toples, ditambahkan dengan etanol $70 \%$, ditutup dan dibiarkan selama dua hari terlindung dari sinar matahari. Kemudian disaring sehingga didapatkan maserat. Ampas dimaserasi lagi dengan menggunakan metode yang sama sampai didapat maaserat yang jernih. Kemudian uapkan maserat menggunakan vakum evaporator suhu $40{ }^{\circ} \mathrm{C}$ sampai didapat ektrak yang kental. 
Skrining Fitokimia. Skrining fitokimia dilakukan terhadap metabolit sekunder alkaloid, saponin, flavonoid dan tannin yang dideteksi menggunakan pereaksi dragendroff, $\mathrm{AlCl}_{3}, \mathrm{FeCl}_{3}$ dan LibermanBurchad. Metode yang digunakan adalah Kromatografi Lapis Tipis (KLT). KLT dilakukan dengan fase diam silica gel $\mathrm{GF}_{254}$ dan dilakukan optimasi fase gerak.

Penentuan Kadar Fenolik Total. 1. Penentuan panjang gelombang maksimum. Sebanyak $0,5 \mathrm{~mL}$ larutan stok asam galat $100 \mu \mathrm{g} / \mathrm{mL}$ ditambahkan dengan $2 \mathrm{~mL}$ reagen Folin-Ciocalteu dan $4 \mathrm{~mL}$ natrium karbonat $1 \mathrm{M}$. Lalu baca absorbansi pada panjang gelombang 200-800 $\mathrm{nm}$.

2. Penentuan operating time (OT). Sebanyak 0,5 $\mathrm{mL}$ larutan stok asam galat $100 \mu \mathrm{g} / \mathrm{mL}$ ditambahkan dengan $2 \mathrm{~mL}$ reagen Folin-Ciocalteu dan $4 \mathrm{~mL}$ natrium karbonat $1 \mathrm{M}$. lalu baca absorbansi pada panjang gelombang maksimum. Baca absorbansi larutan setiap 1 menit selama 60 menit.

3. Penentuan kurva baku asam galat. Larutan asam galat dengan konsentrasi 10, 20, 40, 60 dan $80 \mu \mathrm{g} /$ $\mathrm{mL}$ diambil sebanyak $0,5 \mathrm{~mL}$ kemudian ditambahkan dengan $2 \mathrm{~mL}$ reagen Folin-Ciocalteu dan $4 \mathrm{~mL}$ natrium karbonat $1 \mathrm{M}$. Diamkan selama operating time lalu baca absorbansinya pada panjang gelombang maksimum.

4. Penentuan kadar fenolik total. Melarutkan $10 \mathrm{mg}$ sampel ekstrak kental daun kelor dilarutkan dengan etanol $70 \%$ ad $10 \mathrm{~mL}$, didapat konsentrasi sampel $1000 \mu \mathrm{g} / \mathrm{mL}$. Kemudian diambil $0,5 \mathrm{~mL}$ sampel ditambahkan dengan $2 \mathrm{~mL}$ reagen Folin-Ciocalteu dan $4 \mathrm{~mL}$ natrium karbonat $1 \mathrm{M}$. Diamkan selama operating time lalu baca absorbansinya pada panjang gelombang maksimum. Lakukan replikasi sebanyak 3 kali.

Penentuan Kadar Flavonoid Total. 1. Penentuan panjang gelombang maksimum. Sebanyak $1 \mathrm{~mL}$ larutan stok kuersetin $100 \mu \mathrm{g} / \mathrm{mL}$ ditambakan dengan $1 \mathrm{~mL} \mathrm{AlCl}{ }_{3} 10 \%$ dan $8 \mathrm{~mL}$ asam asetat 5\%. Kemudian diukur absorbansinya pada panjang gelombang $330-450 \mathrm{~nm}$. 2. Penentuan operating time (OT). Sebanyak $1 \mathrm{~mL}$ larutan stok kuersetin $100 \mathrm{ppm}$ ditambakan dengan $1 \mathrm{~mL} \mathrm{AlCl}_{3} 10 \%$ dan $8 \mathrm{~mL}$ asam asetat $5 \%$. Kemudian diukur absorbansinya pada panjang gelombang maksimum. Absorbansi dibaca setiap 2 menit sampai diperoleh absorbansi yang stabil. 3. Penentuan kurva baku kuersetin. Larutan kuersetin dengan konsentrasi 60, 70, 80, 90 dan 100 $\mu \mathrm{g} / \mathrm{mL}$ diambil sebanyak $1 \mathrm{~mL}$ kemudian tambakan dengan $1 \mathrm{~mL} \mathrm{AlCl}{ }_{3} 10 \%$ dan $8 \mathrm{~mL}$ asam asetat $5 \%$. Diamkan selama operating time Kemudian diukur absorbansinya pada panjang gelombang maksimum. 4. Penetapan kadar flavonoid total. Sampel ekstrak kental daun kelor 1000 ppm diambil sebanyak $1 \mathrm{~mL}$ kemudian tambakan dengan $1 \mathrm{~mL} \mathrm{AlCl}_{3} \quad 10 \%$ dan $8 \mathrm{~mL}$ asam asetat $5 \%$. Diamkan selama operating time, kemudian diukur absorbansinya pada panjang gelombang maksimum. Lakukan replikasi sebanyak 3 kali.

Uji Aktivitas Antioksidan dengan Metode Beta Caroten Bleaching (BCB). Buatlah emulsi beta karoten - asam linoleat dengan cara $0,5 \mathrm{mg}$ Beta karoten dilarutkan dengan $1 \mathrm{~mL}$ kloroform. Kemudian ditambahkan $25 \mu \mathrm{L}$ asam linoleat dan $200 \mathrm{mg}$ Tween 40 lalu cukupkan dengan aquadest hingga $100 \mathrm{~mL}$. kemudian campuran divortex hingga didapat larutan yang transparan. Larutan sampel dengan masingmasing konsentrasi $(250,300,350,400$ dan $450 \mu \mathrm{g} /$ $\mathrm{mL}$ ) diambil 0,5 $\mathrm{ml}$ kemudian ditambah dengan 1,5 $\mathrm{ml}$ emulsi beta carotene-asam linoleat. Campuran selanjutnya diinkubasi pada suhu $50{ }^{\circ} \mathrm{C}$ selama 90 menit, setiap interval 30 menit dibaca serapannya. Serapan dibaca dengan Spektrofotometer UV-Vis pada panjang gelombang $413 \mathrm{~nm}$. Untuk kontrol positif digunakan kuersetin, dan kontrol negatif digunakan $2 \mathrm{~mL}$ emulsi beta karoten ditambah $0,2 \mathrm{~mL}$ etanol.

Uji Aktivitas Anti Aging dengan Inhibitor Kolagenase. $20 \mu \mathrm{L}$ larutan sampel dan ditambahkan $10 \mu \mathrm{L}$ Collagenase $(0,35 \mathrm{U} / \mathrm{mL})$ dan ditambah dengan $50 \mu \mathrm{L}$ Collagenase Assay Buffer ke dalam mikroplate 96 well. 1,10-Phenantrolin digunakan sebagai inhibitor control untuk pembanding. $90 \mu \mathrm{L}$ larutan buffer sebagai blanko dan $70 \mu \mathrm{L}$ larutan buffer yag ditambah dengan $10 \mu \mathrm{L}$ Collagenase sebagai kontrol negatif. Inkubasi selama 30 menit pada suhu $37{ }^{\circ} \mathrm{C}$, kemudian tambahkan substrat sebanyak $20 \mu \mathrm{L}$ dan ukur serapan pada panjang gelombang $435 \mathrm{~nm}$.

Formulasi Body Butter. Fase minyak (asam stearat, setil alkohol, oleum cacao, oleum cocos) ditambahkan dengan nipasol kemudian masukkan kedalam cawan dan panaskan diatas waterbath dengan suhu dibawah $70{ }^{\circ} \mathrm{C}$ sampai lebur. Fase air (sebagian trietanolamin dan gliserin) ditambah nipagin dan sebagian akuadest dimasukkan kedalam cawan kemudian dileburkan dengan suhu yang sama. Ekstrak daun kelor ditambah dengan TEA dan gliserin, kemudian dicampur sampai homogen. Campuran ekstrak dituang ke dalam fase air, kemudian ditambah dengan oleum olivarum. Campuran ini segera dimasukkan ke dalam fase minyak yang sudah lebur sempurna. BHT ditambahkan ke dalam fase air dan kemudian dicampurkan ke dalam fase minyak dan dilakukan pengadukan dengan kecepatan tinggi sambil ditambahkan air. Pengadukan dilakukan sampai suhu campuran turun dan terbentuk masa yang kental, lembut dan homogen.

Evaluasi Sediaan. Evaluasi sediaan yang dilakukan meliputi: 
1. Uji organoleptis. Dilakukan pengamatan visual terhadap bau, warna dan bentuk body butter selama 7 hari. 2. Pemeriksaan homogenitas. Pengujian dilakukan dengan mengoleskan body butter pada obyek glass. Hasil yang homogen tidak menghasilkan butiran yang kasar. 3. Uji daya sebar. Ditimbang sebanyak 0,5 gram sampel kemudian diletakkan pada kaca bulat dan ditunggu selama 1 menit. Diameter sebar diukur. Selanjutnya ditambah beban 50 gram, 100 gram, 150 gram dan diamkan selama 1 menit lalu diameter diukur. 4. Uji daya lekat. Sampel diletakkan secukupnya diatas object glass yang sudah dipasang pada alat uji dan letakkan object glass lain diatasnya, lalu ditekan dengan beban $1 \mathrm{~kg}$ selama 5 menit, kemudian beban seberat 80 gram dilepaskan dan dicacat waktunya hingga object glass terlepas. 5. Pengukuran $\mathrm{pH}$. Dilakukan pengukuran $\mathrm{pH}$ sediaan body butter dengan menggunakan stik pH.6. Pengukuran viskositas. Ditimbang sebanyak 15 gram body butter diukur viskositasnya dengan menggunakan viscometer menggunakan kecepatan dan spindle yang sesuai.7. Uji stabilitas dengan freethraw cycling. Body butter disimpan pada suhu $4{ }^{\circ} \mathrm{C}$ selama 24 jam dan pada suhu $45{ }^{\circ} \mathrm{C}$ selama 24 jam (siklus), pengujian dilakukan sebanyak 3 siklus dan diamati perunahan fisik dari sediaan dari awal sampai akhir siklus yang meliputi organoleptis, viskositas, $\mathrm{pH}$, daya sebar dan daya lekat.

\section{HASIL DAN PEMBAHASAN}

Preparasi Sampel. Sampel yang digunakan pada penelitian ini adalah daun Kelor dengan spesies Moringa oleifera L. Pada penelitian ini digunakan daun Kelor sebanyak $2 \mathrm{~kg}$. Bobot simplisia yang dihasilkan setelah melalui tahapan pembuatan simplisia adalah $200 \mathrm{mg}$ yang berwarna hijau dan bertekstur halus.

Ekstraksi. Proses ekstraksi daun kelor menggunakan metode maserasi. Maserasi merupakan metode ekstraksi tanpa pemanasan sehingga dapat mencegah kerusakan komponen kimia yang tidak tahan terhadap pemanasan. Metode ini cocok untuk mengekstrak zat aktif yang berpotensi sebagai antioksidan yang sebagian besar merupakan komponen kimia yang tidak tahan terhadap panas. Proses maserasi dilakukan dengan meggunakan pelarut etanol. Etanol yang digunakan yaitu etanol $70 \%$. Pelarut etanol dipilih untuk proses ekstraksi karena dapat melarutkan hamper semua metabolit sekunder(6). Selain itu disbanding pelarut lain, etanol mempunyai sifat mudak menguap sehingga pelarut pada ekstrak mudah diuapkan tanpa merusak kandungan kimia yang terdapat dalam ekstrak.
Maserasi dilakukan dengan melarutkan 200 gram serbuk daun Kelor dengan pelarut etanol 70\% sebanyak 2 liter selama 3 hari dan hasil ekstraksi dipekatkan menggunakan rotary evaporator, kemudian diuapkan sehingga didapatkan ekstrak kental sebanyak 75,42 gram dan diperoleh rendemen ekstrak daun kelor sebesar $37,1 \%$.

Skrining Fitokimia. Ekstrak daun kelor mengandung metabolit sekunder flavonoid, alkaloid, saponin dan tannin. Dimana flavonoid merupakan senyawa yang berkhasiat sebagai antioksidan. Hasil penapisan fitokimia ditampilkan pada Gambar 1 dan Tabel 1 dibawah ini.

Penetapan Fenolik Total. Penetapan fenolik total bertujuan untuk mengetahui jumlah fenol yang terdapat pada sampel yang dinyatakan sebagai ekuivalen asam galat atau Gallic Acid Equivalent (GAE). Metode yang digunakan yaitu metode Folin Ciocalteau dikembangkan oleh Singleton dan Rossi. Dimana merupakan metode paling umum digunakan untuk menetapkan kadar fenolik total dalam tanaman. Prinsip dari metode ini adalah dalam suasana basa folin dapat bereaksi kolorimetri dimana gugus hidroksi pada senyawa fenolik akan bereaksi dengan reagen Folin Ciocalteau membentuk kompleks molybdenum-tungsen berwarna biru dan hasil yang diperoleh signifikan dengan ion fenolat. Pekatnya warna biru setara dengan konsentrasi ion fenolik yang terbentuk, artinya semakin besar konsentrasi

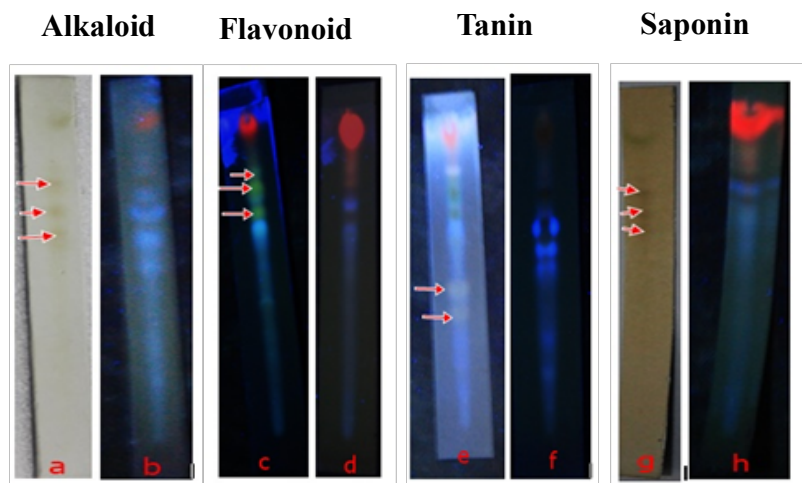

Gambar 1. Hasil penapisan fitokimia ekstrak daun kelor dengan fase gerak B:A:A (3:1:1) dan fase diam silika gel GF254. (a) dan (g) deteksi pada sinar tampak, (b), (c), (d), (e), (f) dan (h) deteksi pada UV366.

senyawa fenolik maka semakin banyak ion fenolik yang ditandai dengan semakin pekatnya warna biru yang dihasilkan(7).

Sebagai standar pada pengukuran total fenolik digunakan asam galat. Asam galat digunakan sebagai standar pengukuran karena asam galat merupakan senyawa polifenol yang terdapat di hampir semua 
Tabel 1. Hasil skrining fitokimia.

\begin{tabular}{lllllr}
\hline Golongan Senyawa & Pereaksi & $\begin{array}{l}\text { Warna pada } \\
\text { Sinar Tampak }\end{array}$ & $\begin{array}{l}\text { Warna pada } \\
\mathrm{UV}_{366}\end{array}$ & $\begin{array}{c}\text { Warna pada } \\
\mathrm{UV}_{254}\end{array}$ & Kesimpulan \\
\hline Alkaloid & Dragendroff & Coklat orange & Biru & Hitam & + \\
Flavonoid & $\mathrm{AlCl}_{3}$ & & Kuning terang & Hitam & + \\
Tannin & $\mathrm{FeCl}_{3}$ & $\begin{array}{l}\text { Abu-abu } \\
\text { kecoklatan }\end{array}$ & Biru & Hitam & + \\
Saponin & $\mathrm{LB}$ & & Merah redup & Hitam & + \\
\hline
\end{tabular}

tanaman. Kandungan fenolik asam organik ini bersifat murni dan stabil. Asam galat tergolong asam fenolik sederhana yang merupakan turunan dari asam hidroksi benzoate( 8 ).

Analisis kandungan fenolik total dilakukan pada panjang gelombang maksimal yang diperoleh yaitu $772 \mathrm{~nm}$. Hasil OT diperoleh pada waktu 31 menit nilai absorbansi yang diperoleh telah stabil, berarti reaksi telah berjalan sempurna. Hasil pengukuran absorbansi larutan standar asam galat dibuat kurva kalibrasi. Persamaan regresi linear yang diperoleh yaitu $y=0,0048 x+0,1707$ dengan koefisien korelasi (R2) 0,9884. Penetapan kadar fenol dari ekstrak etanol daun kelor dilakukan dengan cara $3 x$ replikasi dan dilihat pada Tabel 2.

Berdasarakan hasil penetapan kadar fenolik total ekstrak daun Kelor dinyatakan positif mengandung fenolik total dengan kadar sebesar 16,13 $\pm 0,306$ artinya dalam setiap gram ekstrak daun kelor terdapat fenolik yang setara dengan $16,13 \pm 0,306$ asam galat. Penetapan total fenolik merupakan dasar dilakukannya pengujian aktivitas antioksidan. Hal ini disebabkan karena sebagian besar antioksidan dalam bahan tanaman merupakan senyawa polifenol. Karena diketahui bahwa senyawa fenolik dapat mencegah terjadinya oksidasi(7).

Penetapan Flavonoid Total. Penetapan flavonoid total bertujuan untuk mengetahuin seberapa besar flavonoid yang terkandung pada ekstrak daun kelor, hasilnya berupa nilai kadar flavonoid total dalam sampel. Prinsip dari metode ini adalah pembentukan kompleks yang stabil antara aluminium klorida dengan gugus keto pada atom C-4 dan gugus hidroksi pada atom $\mathrm{C}-3$ atau $\mathrm{C}-5$ yang bertetangga dari golongan flavon dan flavonol ${ }^{(9)}$.

Pengukuran operating time diperoleh pada menit ke-14 dan Panjang gelombang maksimum yang dihasilkan adalah $412 \mathrm{~nm}$. Dari kurva kalibrasi diperoleh persamaan regresi linier yaitu $\mathrm{y}=0,00543 \mathrm{x}+$ 0,05732 dengan nilai koefisien kolerasi (R2) 0,97248. Penetapan kadar flavonoid dari ekstrak etanol daun kelor dilakukan dengan replikasi $3 \mathrm{x}$ dan dilihat pada Tabel 3.

Hasil yang diperoleh menunjukkan bahwa ekstrak etanol daun Kelor dapat dinyatakan positif mengandung flavonoid dengan kadar total yang dihasilkan adalah $5,53 \pm 0,551$ yang artinya pada 100 gram ekstrak daun kelor mengandung 5,53 gram senyawa flavonoid, dimana flavonoid ini merupakan suatu senyawa yang berkhasiat sebagai antioksidan(10).

Tabel 2. Hasil penetapan kadar fenol total ekstrak daun kelor.

\begin{tabular}{cccc}
\hline Replikasi & Absorbansi & Kandungan Fenolik $(\% \mathrm{~b} / \mathrm{b})$ & Rata-rata $(\% \mathrm{~b} / \mathrm{b}) \pm \mathrm{SD}$ \\
\hline 1 & 0.549 & 15,8 & $16,13 \pm 0,306$ \\
2 & 0.558 & 16,2 & \\
3 & 0.563 & 16,4 & \\
\hline
\end{tabular}

Uji Aktivitas Antioksidan dengan Metode Beta Caroten Bleaching (BCB). Pengukuran aktivitas antioksidan dengan metode penghambatan degradasi beta carotene pada penelitian ini menggunakan alat spektrofotmetri visible. Kontrol prositif pada penelitian ini adalah kuersetin.

Ekstrak etanol daun Kelor dapat menghambat proses pemucatan beta karoten. Semakin tinggi konsentrasi penghambatan pemucatannya semakin besar. $\mathrm{IC}_{50}$ ekstrak daun kelor yang di uji menggunakan metode DPPH adalah 97,484 $\mu \mathrm{g} / \mathrm{ml}$ Semakin kecil $\mathrm{IC}_{50}$ maka semakin tinggi aktivitas antioksidan. Secara spesifik suatu senyawa dikatakan kuat apabila $\mathrm{IC}_{50}$ kurang dari $50 \mu \mathrm{g} / \mathrm{mL}$. Apabila lebih dari $200 \mu \mathrm{g} /$ $\mathrm{mL}$ maka zat tersebut kurang aktif namun masih berpotensi sebagai antioksidan(11). Selain itu pada 
peneliatian(5) juga terbukti bahwa ekstrak etanol daun Kelor memiliki aktivitas antioksidan yang dilakukan dengan menggunakan metode FRAP dengan larutan pembanding asam askorbat. Hasil penelitian diperlihatkan pada Gambar 2.

Ekstrak daun Kelor dan batang Kelor mengandung senyawa polifenol, alkaloid, flavonoid, dan tannin yang memiliki efek sebagai sitoprotektif melalui induksi

Tabel 3. Hasil penetapan kadar flavonoid total ekstrak daun kelor.

\begin{tabular}{rccc}
\hline Replikasi & Absorbansi & $\begin{array}{c}\text { Kandungan Flavonoid Total } \\
(\% \mathrm{~b} / \mathrm{b})\end{array}$ & Rata-rata $(\% \mathrm{~b} / \mathrm{b}) \pm \mathrm{SD}$ \\
\hline 1 & 0,321 & 4,9 & $5,53 \pm 0,551$ \\
2 & 0,380 & 5,9 & \\
3 & 0,377 & 5,8 & \\
\hline
\end{tabular}

hydrogen peroksida $\left(\mathrm{H}_{2} \mathrm{O}_{2}\right)$ terhadap sel Fibroblast NIH3T3 dan memiliki aktivitas perlindungan terhadap stres akut dan kronis dibandingkan dengan vitamin $\mathrm{C}(12)$. Semakin kecil $\mathrm{IC}_{50}$ maka semakin tinggi aktivitas antioksidan. Secara spesifik suatu senyawa dikatakan kuat apabila $\mathrm{IC}_{50}$ kurang dari $50 \mu \mathrm{g} / \mathrm{mL}$. Apabila lebih dari $200 \mu \mathrm{g} / \mathrm{mL}$ maka zat tersebut kurang aktif namun masih berpotensi sebagai antioksidan(11).

Uji Aktivitas Anti Aging dengan Inhibitor Kolagenase. Hasil aktivitas anti-aging pada ekstrak daun Kelor diperoleh penghambatan (\%) aktivitas enzim kolagenase oleh adanya inhibitor. Yang dapat dilihat pada Gambar 3 dibawah ini.

Ekstrak daun Kelor pada konsentrasi $1600 \mu \mathrm{g} /$ $\mathrm{mL}$ memberikan hasil penghambatan yang paling tinggi yaitu 47,25\%. Aktivitas penghambatan enzim kolagenase pada daun kelor diduga dipengaruhi oleh kandungan senyawa flavonoid yang berkhasiat sebagai antioksidan dan memberikan efek sinergis terhadap penghambatan enzim kolagenase dalam proses penuaan pada kulit(13). Kolagenase merupakan enzim golongan metalloproteinase (MMP) yang memecah kolagen dan membantu dalam degradasi dari matriks ekstraseluler. Karena MMP merupakan inisiator terjadinya degradasi kolagen, enzim tersebut menjadi indikator proses penuaan kulit karena paparan UV.

Evaluasi Sediaan. Pengamatan organoleptis sediaan "Moringa Body Butter" menunjukkan bentuk yang semi padat, bau khas oleum cacao, dan warna hijau muda. Bau sediaan ini masih kurang menarik sehingga masih perlu penambahan corigen odoris untuk meningkatkan daya tarik. Konsistensi sediaan

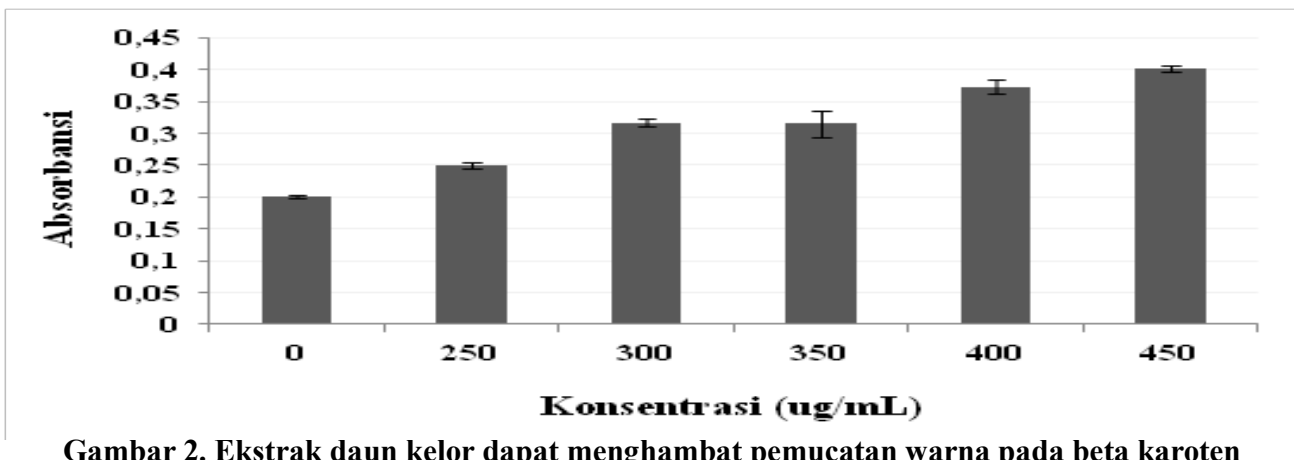

Gambar 2. Ekstrak daun kelor dapat menghambat pemucatan warna pada beta karoten (beta carotene bleaching). Penelitian dilakukan dengan 2 (dua) kali pengulangan.

homogen lembut dan mudah dioleskan. Warna sediaan hijau muda, sudah menarik dan tidak menyebabkan perubahan warna pada saat dioleskan.

Pegujian derajat keasaman menunjukkan $\mathrm{pH}$ 7 sehingga tidak berpotensi menimbulkan iritasi pada kulit. Viskositas sediaan mengalami penurunan seiring dengan lama penyimpanan. Konsistensi sediaan tersebut semakin lama akan semakin encer, hal tersebut akan berpengaruh terhadap hasil untuk daya lekat dan daya sebar, dimana apabila viskositas semakin kecil maka daya sebar akan semakin lebar dan untuk daya lekat akan semakin cepat. Untuk memperbaiki sifat fisik ini diperlukan optimasi komposisi sediaan sehingga diperoleh sediaan yang lebih baik. Pengujian daya sebar dan daya lekat masih menunjukkan hasil yang kurang baik sehingga juga memerlukan modifikasi komposisi sediaan.

Uji freeze-thaw cycling dilakukan untuk melihat pengaruh suhu terhadap sediaan body butter selama penyimpanan pada dua suhu yang berbeda yaitu kondisi beku (freeze) pada suhu $4{ }^{\circ} \mathrm{C}$ dan meleleh (thaw) pada suhu $45^{\circ} \mathrm{C}$. 


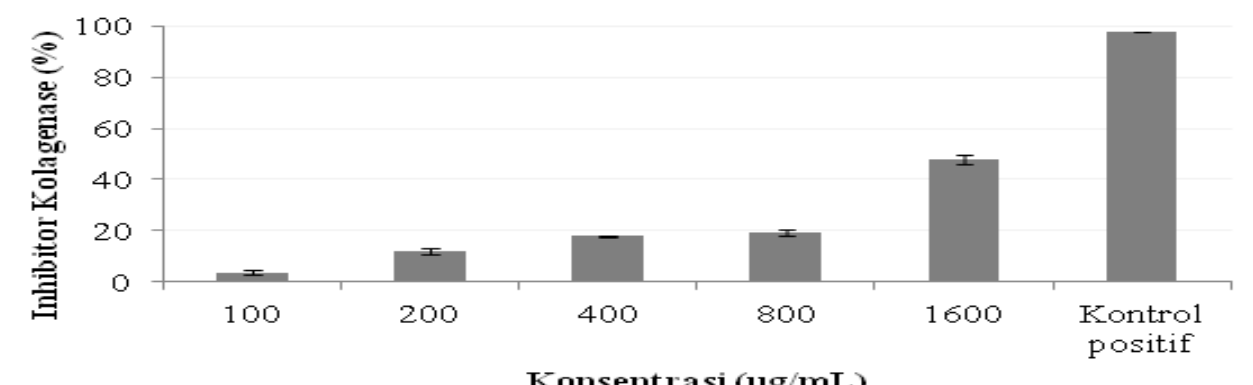

Gambar 3. Ekstrak daun kelor dapat menghambat aktivitas kolagenase sebesar $47 \%$ pada konsentrasi $1600 \mathrm{ppm}$. Control positif menunjukkan penghambatan sebesar $98 \%$.

\section{SIMPULAN}

Berdasarkan hasil uji ekstrak daun Kelor dapat berpotensi sebagai antioksidan dan anti-aging dengan menghambat inhibitor kolagenase hampir 50\% sehingga sediaan body butter yang dihasilkan dapat digunakan untuk mencegah terjadinya penuaan dini. Sediaan moringa body butter masih memerlukan optimasi komposisi sediaan agar diperoleh sediaan yang lebih baik.

Tabel 4. Hasil uji stabilitas sediaan Moringa Body Butter.

\begin{tabular}{|c|c|c|c|c|}
\hline \multirow{2}{*}{ No. } & \multirow{2}{*}{ Parameter } & \multicolumn{3}{|c|}{ Formulasi } \\
\hline & & Rep 1 & Rep 2 & Rep 3 \\
\hline 1. & $\begin{array}{l}\text { Organoleptis } \\
\text { a. Bentuk } \\
\text { b. Bau } \\
\text { c. Warna } \\
\text { Homogenitas }\end{array}$ & $\begin{array}{l}\text { Semi padat } \\
\text { Oleum Cacao } \\
\text { Hijau muda } \\
\text { Homogen }\end{array}$ & $\begin{array}{l}\text { Semi padat } \\
\text { Oleum Cacao } \\
\text { Hijau muda } \\
\text { Homogen }\end{array}$ & $\begin{array}{l}\text { Semi padat } \\
\text { Oleum Cacao } \\
\text { Hijau muda } \\
\text { Homogen }\end{array}$ \\
\hline 3. & $\mathrm{pH}$ & 7 & 7 & 7 \\
\hline 4. & $\begin{array}{l}\text { Viskositas } \\
\text { Siklus I } \\
\text { Siklus II } \\
\text { Siklus III }\end{array}$ & $\begin{array}{l}9.230 \mathrm{cP} \\
6.200 \mathrm{cP} \\
4.950 \mathrm{cP} \\
2.200 \mathrm{cP}\end{array}$ & $\begin{array}{l}9.070 \mathrm{cP} \\
6.550 \mathrm{cP} \\
4.180 \mathrm{cP} \\
2.630 \mathrm{cP}\end{array}$ & $\begin{array}{l}9.550 \mathrm{cP} \\
6.710 \mathrm{cP} \\
4.240 \mathrm{cP} \\
2.820 \mathrm{cP}\end{array}$ \\
\hline 5. & Daya Lekat (detik) & $\begin{array}{l}3,07 \\
2,76 \\
2,57 \\
1,85\end{array}$ & $\begin{array}{l}2,93 \\
2,44 \\
1,97 \\
1,27\end{array}$ & $\begin{array}{l}2,87 \\
2,21 \\
1,99 \\
1,39\end{array}$ \\
\hline 6. & $\begin{array}{l}\text { Daya Sebar (cm) } \\
\text { Siklus I } \\
\text { Siklus II } \\
\text { Siklus III }\end{array}$ & $\begin{array}{l}3,75 \\
3,85 \\
4,64 \\
5,27\end{array}$ & $\begin{array}{c}3,69 \\
3,9 \\
4,19 \\
4,62\end{array}$ & $\begin{array}{l}3,94 \\
4,17 \\
4,23 \\
4,42\end{array}$ \\
\hline
\end{tabular}




\section{DAFTAR PUSTAKA}

1. WHO. WHO report on the global tobacco epidemic 2017: monitoring tobacco use and prevention policies, Geneva, Licence: CC BY-NC-SA 3.0 IGO. 2017.

2. Toripah S, Abidjulu J, dan Wehantouw F. Aktivitas antioksidan dan kandungan total fenolik ekstrak daun kelor (Moringa oleifera L.). Jurnal Ilmiah Farmasi. 2016. 3(4):2303-2493.

3. Hasanah U, Yusriyadi dan Khumaidi A. Formulasi gel ekstrak etanol daun kelor (Moringa oleifera Lam.). Online Journal of Natural Science. 2017. 6(1) :46-57

4. Putra I, Dharmayudha A, dan Sudimartini, L.Identifikasi senyawa kimia ekstrak etanol daun kelor (Moringa oleifera L.) di Bali. Indonesia Medicus Veterinus. 2016. 5(5):464-473.

5. Maryam S, Baits $M$ dan Nadia A. Pengukuran aktivitas antioksidan ekstrak etanol daun kelor (Moringa oleifera Lam.) menggunakan metode FRAP (Ferric Reducing Antioxidant Power). Jurnal Fitofarmaka Indonesia. 2016. 2(2).

6. Darwis D. Teknik dasar laboratorium dalan penelitian senyawa bahan alam hayati, workshop pengembangan sumber daya manusia dalam bidang kimia organik bahan alam hayati. FMIPA Universitas Andalas. Padang. 2000.

7. Sari A. dan Ayuchrcaria N. Penetapan kadar fenolik total dan flavonoid total ekstrak beras hitam (Oryza sativa L.) dari Kalimantan Selatan. Jurnal Ilmiah Ibnu sina. 2017. 2(2):327-335.

8. Hasim, Falah S. dan Dewi L. Effect of boiled Cassava leaves (Manihot esculenta Carntz.) on total phenolic, flavonoid and its antioxidant activity. Current bhiocemistry. 2016.3(3):116-127.

9. Azizah D, Kumolowati E dan Faramayuda F. Penetapan kadar flavonoid metode $\mathrm{AlCl}_{3}$ pada ekstrak methanol kulit buah kakao (Theobroma cacao L.). Kartika jurnal ilmiah farmasi. 2014. 2 (2):2354-6565.

10. Rohyani I, Aryanti E dan Suripto. Kandungan fitokimia beberapa jenis tumbuhan lokal yang sering dimanfaatkan sebagai bahan baku obat di Pulau Lombok. 2015. 1(2):2407-8050.

11. Yuliani $N$ dan Dienina D. Uji aktivitas antioksidan infusa daun Kelor Moringa oleifera L. dengan metode 1,1 diphenyl-2-pycrilhydrazil (DPPH). Jurnal info kesehatan. 2015. 14(2).

12. Ghalyati DA. Uji aktivitas sitoprotektif ekstrak daun dan batang Kelor (Moringa oleifera L.) pada induksi $\mathrm{H}_{2} \mathrm{O}_{2}$ terhadap sel fibroblast NH3T3. Skripsi. Purwokerto. Fakultas Farmasi: Universitas Muhammadiyah Purwokerto. 2017.

13. Sugiartini $\mathrm{N}$ dan Nining E. Formulasi krim ekstrak daun Kelor (Moringa oleifera) sebagai Sediaan Anti-aging. Periodical of Dermatology and Venereology. 2017.29(1). 